\title{
Video Article \\ Integrated Cell Manipulation Platform Coupled with the Single-probe for Mass Spectrometry Analysis of Drugs and Metabolites in Single Suspension Cells
}

\author{
Shawna J. Standke ${ }^{1}$, Devon H. Colby ${ }^{1}$, Ryan C. Bensen ${ }^{1}$, Anthony W. G. Burgett ${ }^{1}$, Zhibo Yang ${ }^{1}$ \\ ${ }^{1}$ Department of Chemistry and Biochemistry, University of Oklahoma \\ Correspondence to: Anthony W. G. Burgett at anthony.burgett@ou.edu, Zhibo Yang at zhibo.yang@ou.edu
}

URL: https://www.jove.com/video/59875

DOI: doi:10.3791/59875

Keywords: Chemistry, Issue 148, Single cell mass spectrometry, suspension cells, integrated cell manipulation platform, Single-probe, ambient ionization, microscale sampling

Date Published: 6/21/2019

Citation: Standke, S.J., Colby, D.H., Bensen, R.C., Burgett, A.W., Yang, Z. Integrated Cell Manipulation Platform Coupled with the Single-probe for Mass Spectrometry Analysis of Drugs and Metabolites in Single Suspension Cells. J. Vis. Exp. (148), e59875, doi:10.3791/59875 (2019).

\section{Abstract}

Single cell mass spectrometry (SCMS) enables sensitive detection and accurate analysis of broad ranges of cellular species on the individualcell level. The single-probe, a microscale sampling and ionization device, can be coupled with a mass spectrometer for on-line, rapid SCMS analysis of cellular constituents under ambient conditions. Previously, the single-probe SCMS technique was primarily used to measure cells immobilized onto a substrate, limiting the types of cells for studies. In the current study, the single-probe SCMS technology has been integrated with a cell manipulation system, typically used for in vitro fertilization. This integrated cell manipulation and analysis platform uses a cell-selection probe to capture identified individual floating cells and transfer the cells to the single-probe tip for microscale lysis, followed by immediate mass spectrometry analysis. This capture and transfer process removes the cells from the surrounding solution prior to analysis, minimizing the introduction of matrix molecules in the mass spectrometry analysis. This integrated setup is capable of SCMS analysis of targeted patientisolated cells present in body fluids samples (e.g., urine, blood, saliva, etc.), allowing for potential applications of SCMS analysis to human medicine and disease biology.

\section{Video Link}

The video component of this article can be found at https://www.jove.com/video/59875/

\section{Introduction}

Human biology, especially disease biology, is increasingly understood to be the result of activities on the level of individual cells, but the traditional analytical methods, such as liquid chromatography mass spectrometry (LCMS), are generally used to analyze samples prepared from populations of cells, whereas the acquired molecular information cannot accurately represent the chemical processes on the individual-cell level. These standard, traditional methods are unable to discern the effects of cellular heterogeneity on an analytical measurement, and the process of destroying and mixing the cells to prepare the lysate potentially leads to the alteration or loss of cellular components ${ }^{1,2}$. These limitations of traditional methods are especially important in the analysis of patient cells, in which the obtained samples can contain a complex mixture of many different cell types. To overcome these deficiencies, single cell molecular analysis methods, including single cell mass spectrometry (SCMS) methods, are increasingly being developed and applied to bioanalysis, especially of cellular metabolites and low molecular weight biomolecules ${ }^{3,4}$.

The first SCMS techniques developed used vacuum-based techniques to perform the analyses under non-ambient conditions ${ }^{2,5,6,7,8,9,10,11}$. Non-ambient SCMS techniques are capable of analyzing cellular lipids and metabolites, but require sample pretreatment under artificial conditions, and therefore are not suitable for real-time analysis. The sample preparation process for non-ambient analysis includes the addition of matrix components, and this preparation can alter cellular components from their natural environment ${ }^{12}$. Therefore, ambient mass spectrometry (MS) techniques, which do not require a vacuum for the sampling environment, are utilized to analyze cells in a near-native environment. Not having a vacuum environment allows for versatility in the experimental design; cameras can be added to monitor the cellular process and softer ionization techniques can be combined with separation techniques to receive better information from each single-cell experiment $4^{4,12,13,14,15,16,17,18,19,20,21,22,23,24,25,26,27,28,29,30,31,32,33,34,35,36,37,38,39,40,41,42}$.

The single-probe SCMS method is an ambient technique that analyzes live, mammalian cancer cell lines in a near-native environment ${ }^{21,43,44,45,46}$ In addition, the single-probe device has been used for other mass spectrometry applications, including analysis of extracellular molecules in multicellular spheroids and MS imaging of tissues ${ }^{47,48,49,50,51,52}$. However, since cell immobilization on substrates is required for this method, suspension cells cannot be directly analyzed using this technique ${ }^{3,53}$. Therefore, the single-probe SCMS system could not be directly used to sample non-adherent single cells, such as non-adherent cell lines or suspension cells isolated from a patient's blood or other bodily fluids ${ }^{54}$. In this work, an integrated cell manipulation platform (ICMP) is coupled with the single-probe SCMS technique to analyze live, suspension cells on-line with minimal sample preparation (Figure 1$)^{46}$. The ICMP consists of an inverted microscope to monitor cell selection, a glass cellselection probe, a microinjector to capture individual floating cells, a heated plate to maintain cellular temperature, two cell manipulation systems to control spatial movements of both the glass cell-selection probe and single-probe, and a digital microscope to observe cell transfer from the 
cell-selection probe tip to the single-probe tip. The fabrication of the single-probe is detailed in previous publications and will not be addressed here $^{21,48}$. The ICMP/single-probe system is coupled to a high resolution mass spectrometer. This integrated setup allows for the sampling of identified single cells from complex biological samples with minimal effects from matrix molecules.

\section{Protocol}

\section{Glass cell-selection probe fabrication}

1. Convert single-bore glass tubing into a tapered probe with a sharp tip.

1. Place a single-bore glass tube (ID: $0.3 \mathrm{~mm}, \mathrm{OD}: 1.1 \mathrm{~mm}$ ) into the clamps of a vertical pipette holder, centering the glass with respect to the heating coil and tighten to secure the tube in place. The heating coil is comprised of an 18-gauge nickel-chromium resistance wire $(\sim 60 \mathrm{~mm}$ in length) coiled around a metal rod (diameter $=3.90 \mathrm{~mm}) 2.5$ times.

2. Set the glass tubing with temperature program 19.5 (manufacturer's unit). This parameter can be modified for a particular instrument.

3. Set the solenoid plunger at 4 (manufacturer's unit). This parameter can be modified for a particular instrument.

4. Trigger the solenoid to pull the glass tubing. This step creates two probes fused at the tip.

5. Use tweezers to cut $\sim 1 \mathrm{~mm}$ away from the tip of each probe, creating an orifice of $\sim 10 \mu \mathrm{m}$ in diameter at the probe tip.

2. Bend the glass probe for easy coupling to the ICMP/single-probe SCMS setup.

1. Set a pulled glass probe into the microforge, positioning the tip $\sim 3 \mathrm{~mm}$ above the platinum heating wire.

2. Turn the heat on the platinum wire to $30 \%$ of the maximum temperature.

3. Bend the probe $\sim 45^{\circ}$ from the original position (Figure 2).

\section{Integrated cell manipulation platform assembly}

1. Place the inverted microscope, microinjector, and two cell manipulation systems on a motorized table for easy coupling with the mass spectrometer.

1. Modify one of the cell manipulation systems to accommodate a single-probe by replacing the end with an arm clamp.

2. Use a plastic syringe with a needle to fill the microinjector with mineral oil. Avoid bubbles in the tubing as this will affect suctioning

3. Replace the stage insert of the inverted microscope with the heated plate. Set the heated plate at $37^{\circ} \mathrm{C}$ prior to analysis.

2. Set up the glass cell-selection device.

1. Insert the glass cell-selection probe inside the metal holder of the microinjector by placing the long (non-bent) side into the capillary holder and tightening the screw to secure the probe in place. Position the probe tip's angle parallel to the heated plate.

CAUTION: The glass probe is very sharp and fragile, and it breaks easily. Protect your eyes and be extra cautious while inserting the probe into the microinjector.

2. Secure the metal holder of the microinjector into the cell manipulation system. Position the probe tip near the middle of the inverted microscope light.

\section{Create an extended ion transfer tube for the mass spectrometer inlet}

1. Use a metal cutter to cut a piece of stainless-steel tubing (OD: $0.0625(1 / 16)$ in, ID: $0.021 \mathrm{in}) \sim 250 \mathrm{~mm}$ in length

2. Measure $135 \mathrm{~mm}$ from the end and place a metal feral so $\sim 135 \mathrm{~mm}$ will be exposed to the atmosphere and $\sim 115 \mathrm{~mm}$ will be inside the mass spectrometer. Secure the feral using two wrenches to tighten it.

\section{Couple the ICMP with a single-probe setup}

1. Secure the glass slide containing the single-probe into the arm clamp of the cell manipulation system.

NOTE: Single-probes are fabricated according to a previously-published protocol ${ }^{48}$ with two minor changes in the current study: the nano-ESI emitter is made longer for easy coupling to the mass spectrometer, and the single-probes are glued to the glass side on the right-hand side to avoid interfering with the spatial movement of the glass cell-selection device (Figure 2).

2. Connect the solvent-providing capillary to a conductive union by placing the capillary into the sleeve (1/16 x .005 in) of the plastic ferrule and finger-tightening the fitting.

1. Connect the other side of the conductive union to a capillary (ID: $40 \mu \mathrm{m}, \mathrm{OD}: 150 \mu \mathrm{m}$ ), which is connected to a syringe containing the sampling solvent, by placing the capillary into the sleeve $(1 / 32 \times .007 \mathrm{in})$ and tightening the fitting. Use acetonitrile with $0.1 \%$ formic acid as the sampling solvent in these experiments.

NOTE: The sampling solvent is flexible, but it should primarily contain acetonitrile (or acetonitrile with formic acid for better ionization) for a rapid microscale cell lysis.

2. Secure the syringe into the syringe pump on the mass spectrometer.

3. Place the ionization voltage cord onto a copper wire attached to the conductive union.

3. Position the nano-ESI emitter $\sim 1 \mathrm{~mm}$ to the orifice of the extended ion transfer tube.

1. Use the cell manipulation system to control the spatial movements of the Single-probe and position the nano-ESI emitter centrally in front of the extended ion transfer tubing. 


\section{Suspended cell sample preparation}

1. The day before analysis ( 18-24 h), seed out cells for testing in a cell culture flask (T25). K562 human myeloid leukemia cells are used as models in this study.

1. Heat $1 x$ phosphate buffered saline (PBS) and Roswell Park Memorial Institute (RPMI) medium supplemented with $10 \%$ synthetic fetal bovine serum (FBS) and $1 \%$ penicillin-streptomycin at $37^{\circ} \mathrm{C}$ for $30 \mathrm{~min}$.

2. Seed $\sim 1 \times 10^{6}$ cells in a total volume of $10 \mathrm{~mL}$ by combining cells with warm medium. In general, use a 10 -mL pipette to place $8 \mathrm{~mL}$ of RPMI medium into a cell culture flask. Then, use a $2 \mathrm{~mL}$ pipette to put $2 \mathrm{~mL}$ of confluent $\mathrm{K} 562$ cells the medium for $\sim 1 \times 10^{6}$ cells.

3. Incubate the cells at $37^{\circ} \mathrm{C}$ and $5 \% \mathrm{CO}_{2}$ until analysis.

2. Prepare cells for analysis.

1. Pipette cells from the cell culture flask into a $15-\mathrm{mL}$ centrifuge tube.

2. Spin cells down at $400 \times g$ and $37^{\circ} \mathrm{C}$ for $5 \mathrm{~min}$ and discard the supernatant.

3. Resuspend cells in $4 \mathrm{~mL}$ of RPMI medium containing the drug compound at the desired treatment concentration. NOTE: For analysis of control cells, resuspend the cells in $4 \mathrm{~mL}$ of RPMI medium and skip to Step 6.

4. Incubate the cells for the duration of the treatment time at $37^{\circ} \mathrm{C}$ and $5 \% \mathrm{CO}_{2}$.

5. Spin cells down at $400 \times g$ and $37^{\circ} \mathrm{C}$ for $5 \mathrm{~min}$. Aspirate the supernatant.

6. Cells are resuspended in $10 \mathrm{~mL}$ of PBS, and centrifuge at $400 \times g$ and $37^{\circ} \mathrm{C}$ for $5 \mathrm{~min}$. After spinning, discard the supernatant. Repeat this step 3 times to minimize detection of drug from extracellular constituents.

7. Resuspend cells in $4 \mathrm{~mL}$ of PBS for analysis.

\section{Perform SCMS measurements using the ICMP/single-probe setup}

1. Customize parameters for the mass spectrometer for the experiment.

1. Under the Scan Mode heading of the instrument software, select Define Scan. Use a resolution of $60,000 \mathrm{~m} / \Delta \mathrm{m}$ at $\mathrm{m} / \mathrm{z} 400,1$ microscan, 100 ms maximum injection time, and automatic gain control (AGC) on. A mass range (m/z) of 100-1000 was utilized for the experiments. Parameters can be modified based on the instrument model.

2. Under Syringe Pump, select a flow rate of $150 \mathrm{~nL} / \mathrm{min}$. Flow rate needs to be optimized for each experiment.

3. Select NSI Source and apply a voltage of $\sim 4.5 \mathrm{kV}$. This parameter also needs to be optimized for each experiment.

2. Turn on the inverted microscope (with 40x magnification selected for both the top plate and bottom lens) and connect it to the USB-port of a laptop to capture live-video feeds. Turn on the heated plate and set it to $37^{\circ} \mathrm{C}$.

3. On the computer, go to the Acquire Data tab, and select Continuously under Acquire Time.

4. Prepare sample for analysis.

1. Pipette $2-3 \mathrm{~mL}$ of sample into the lid of a small Petri dish ( $35 \mathrm{~mm} \times 12 \mathrm{~mm}$ ).

2. 6.4.2 Position the sample in the center of the light from the inverted microscope on top of the heated plate.

5. Prepare the glass cell-selection probe for analysis. Use the cell manipulation system to move the probe so its tip is focused under the inverted microscope in the same plane as the cells.

6. Select an individual cell for analysis.

1. Use the cell manipulation system to move the cell-selection probe tip to a targeted cell. This process is monitored using the inverted microscope.

NOTE: If the tip of the cell-selection probe cannot be focused in the same plane as the cells, it is possible that the bent part of the probe is not appropriately angled. Adjust the position of the cell-selection probe until both probe tips can be focused along with cells under the microscope.

2. Gently turn the handle of the microinjector to adjust the position of the mineral oil inside the tubing. A gentle suction is provided by the microinjector to secure the targeted cell to the cell-selection probe tip.

NOTE: If the cell cannot be captured by the cell-selection probe through the suction force, check the cell-selection probe to ensure it is fully-inserted into the capillary holder. In addition, inspect the mineral oil levels in the microinjector and tubing, and expel air if there is any.

3. Use the cell manipulation system to move the cell at the cell-selection probe tip to the single-probe tip, using a digital microscope focused on the single-probe tip to monitor this process. When touching, a small acetonitrile droplet at the single-probe tip induces a rapid lyses of the cell, and then cell lysate is immediately ionized for on-line MS analysis.

NOTE: Because the selected cell is secured to the cell-selection probe tip through a gentle suction, this cell can be potentially detached during its transfer to the Single-probe tip. Therefore, if ion signals of typical cellular lipids (see representative results below) are not observed within $5 \mathrm{~s}$, it is possible that the cell became unattached, and the selection of a different cell is needed. 


\section{Representative Results}

First, untreated K562 cells are used to establish the experimental method. In a typical SCMS experiment, obvious changes of mass spectra can be observed from transferring a cell, during the detection of cellular contents, and after finishing the measurement (Figure S1). Three common cellular lipid peaks (phosphatidylcholine, PC), including PC(34:4) ( $\mathrm{m} / \mathrm{z} 754.536), \mathrm{PC}(36: 4)(\mathrm{m} / \mathrm{z} 782.567)$, and $\mathrm{PC}(38: 5)(\mathrm{m} / \mathrm{z}$ 808.583), are monitored to ensure the cell is successfully transferred and cellular contents are detected (Figure S2) ${ }^{21,43,46,55,56}$. If lipid peaks are not seen within $5 \mathrm{~s}$, the mineral oil level in the microinjector is altered to reduce the suction holding the cell at the cell-selection probe tip; caution needs to be taken so that no mineral oil is pushed out from the cell-selection probe. The identity of many PC's in the mass range of $m / z 750-850$ are confirmed using MS/MS on untreated cell lysate samples (Figure 3, Figure S2, Table 1) ${ }^{46}$.

K562 cells are also subjected to treatment with various drug compounds to expand the versatility of the method. K562 cells are incubated with gemcitabine $(1 \mu \mathrm{M})$ and taxol $(1 \mu \mathrm{M})$ for $1 \mathrm{~h}$ and OSW-1 $(100 \mathrm{nM}, 1 \mu \mathrm{M})$ for $4 \mathrm{~h}$ and $2 \mathrm{~h}$, respectively. Cells are then washed with PBS to minimize the detection of drug compounds from extracellular content. The contribution of matrix (e.g., ions from cell culture medium, PBS, and solvent) to mass spectra of cellular contents can be eliminated through data subtraction, due to their significantly different ion signals (Figure S3). All three drug compounds are detected using the ICMP/single-probe MS setup (Figure S4) ${ }^{46}$. These results suggest this method can be used to study intracellular lipids, drugs, and metabolites on the single-cell level from cells in solution in a near-native environment.

(a)

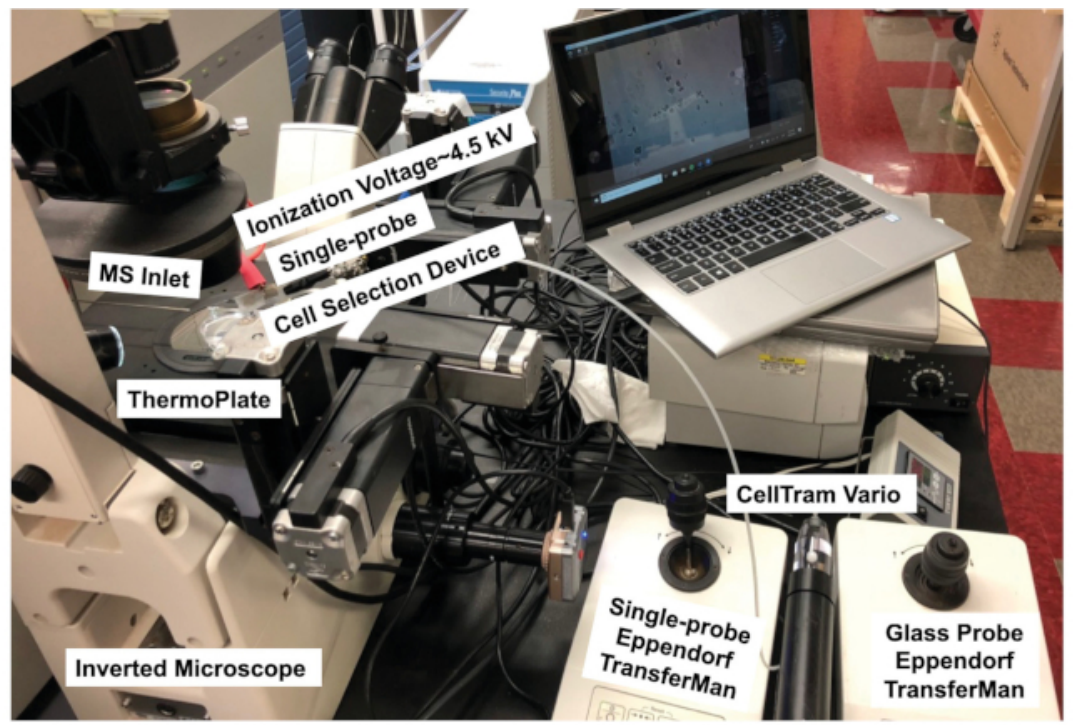

(b)

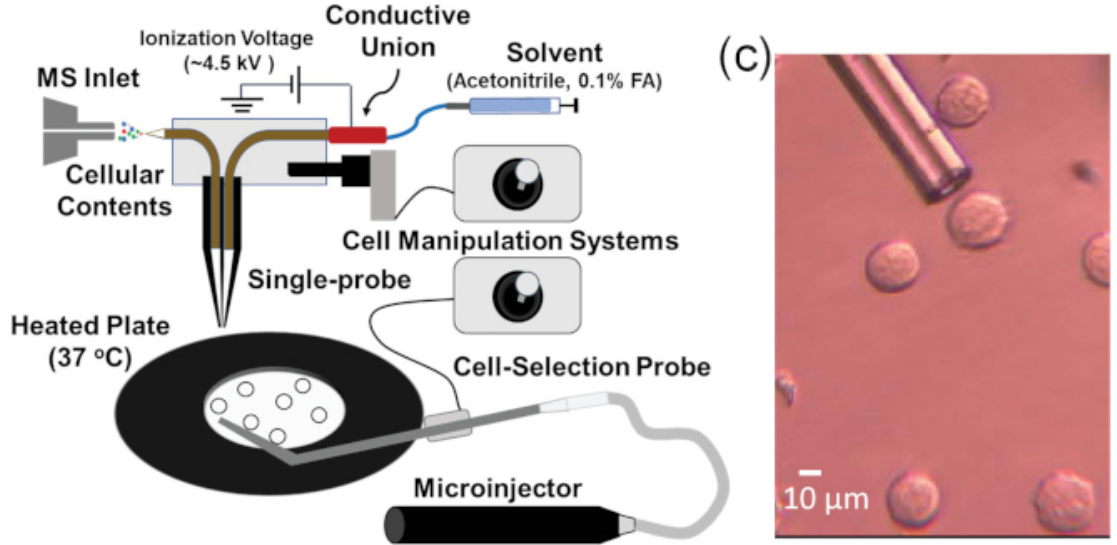

Figure 1. Experimental setup for single suspension cell MS experiments. (A) The integrated cell manipulation platform (ICMP) coupled with a mass spectrometer. (B) Schematic for analysis of suspended cells. (C) Experimental view of K562 cells to be selected using the cell-selection probe. Reprinted with permission from Standke et al. ${ }^{46}$. Copyright 2019 American Chemical Society. Please click here to view a larger version of this figure. 


\section{Modified Single-probe}



\section{Cell-Selection Probe}

Figure 2. Photos of a modified single-probe and a cell-selection probe utilized for single suspension cell MS experiments. Please click here to view a larger version of this figure.



Figure 3. Zoomed-in mass spectrum from a single cell showing the representative species $(\mathrm{m} / \mathbf{z} 750-850)$. Chemical structures are confirmed using MS/MS analysis (Figure S1). Reprinted with permission from Standke et $a^{46}{ }^{4}$. Copyright 2019 American Chemical Society. Please click here to view a larger version of this figure. 


\begin{tabular}{|c|c|c|}
\hline Drug Molecule* & $m / z$ & Mass Error (ppm) \\
\hline$[\text { Gemcitabine }+\mathrm{H}]^{+}$ & 264.076 & 11.32 \\
\hline$[\text { Taxol }+\mathrm{Na}]^{+}$ & 876.318 & 2.74 \\
\hline$[\mathrm{OSW}-1+\mathrm{Na}]^{+}$ & 895.445 & 0.89 \\
\hline \multicolumn{3}{|l|}{ Cellular Lipids } \\
\hline$[\mathrm{PC}(34: 4)+\mathrm{H}]^{+}$ & 754.535 & 3.71 \\
\hline$[\mathrm{PC}(34: 3)+\mathrm{H}]^{+}$ & 756.551 & 3.44 \\
\hline$[\mathrm{PC}(34: 2)+\mathrm{H}]^{+}$ & 758.569 & 0.66 \\
\hline$[\mathrm{PC}(36: 5)+\mathrm{H}]^{+}$ & 780.551 & 3.07 \\
\hline$[\mathrm{PC}(36: 4)+\mathrm{H}]^{+}$ & 782.568 & 2.17 \\
\hline$[\mathrm{PC}(36: 3)+\mathrm{H}]^{+}$ & 784.585 & 0.64 \\
\hline$[\mathrm{PC}(38: 7)+\mathrm{H}]^{+}$ & 804.551 & 4.1 \\
\hline$[\mathrm{PC}(38: 6)+\mathrm{H}]^{+}$ & 806.567 & 2.48 \\
\hline$[\mathrm{PC}(38: 5)+\mathrm{H}]^{+}$ & 808.583 & 2.72 \\
\hline$[\mathrm{PC}(38: 4)+\mathrm{H}]^{+}$ & 810.601 & 0 \\
\hline$[\mathrm{PC}(40: 7)+\mathrm{H}]^{+}$ & 832.583 & 3.12 \\
\hline
\end{tabular}

Table 1. Identified cellular components using the ICMP/Single-probe setup. The detection of all drug compounds were confirmed by comparing the MS/MS results with standard compound.

\section{Discussion}

The integrated cell manipulation and analysis platform is constructed to expand the versatility of the single-probe MS method, allowing for online, rapid analysis of non-adherent cells in a near-native environment. A major advantage of the technique is that minimal sample preparation is required, so the cells are analyzed in conditions that mimic their standard state. Particularly, individual cells of interest can be visually identified and selected, minimizing the influence of matrix effect on MS ionization efficiency while maintaining cells in their natural environment, so the results are more representative cells' native status (Figure S3). This technique can be potentially used to study patient cells suspended in biofluids in future studies. Another advantage of this technique is the flexible selection of the sampling solvent. It is important to include acetonitrile as the main sampling solvent so that microscale lysis can occur rapidly. Potentially, internal standards (e.g., isotopically-labeled drug compounds) can be added into the sampling solvent for quantification of molecules of interest (e.g., drug molecules) from individual cells, including those can play a key role in revolutionizing personalizing drug treatments in the future ${ }^{54}$.

Although this integrated system can be conveniently used to analyze broad ranges of cells, a limitation of the method is that neither the singleprobe nor cell-selection probe is commercially-available; dictating the need for optimization of many parameters (e.g., flow rate, voltage, length between the nano-ESI emitter and ion transfer tubing, etc.) prior to each experiment. In addition, due to the smallness of the Single-probe and cell-selection probe, environmental perturbation (e.g., air flow) may result in difficulties establishing a junction between the two probes. A shortterm solution is the bending of the cell-selection probe close to the end to minimize the length of tapering. Future work includes the development of a housing to enclose the critical parts of the setup to minimize environmental effects. Due to the limited amount of cellular contents and short acquisition time ( 2-3 s) from a cell, MS/MS analysis can be only conducted for relatively abundant species. Other factors influencing the detection sensitivity include the suppressed ionization efficiency due to the introduction of matrix along with the cell and potential ion loss through the extended ion transfer tubing.

\section{Disclosures}

The authors have nothing to disclose.

\section{Acknowledgments}

The authors thank Naga Rama Kothapalli for her work in developing sample preparation for both suspension cells and cell lysate experiments. Additionally, the authors thank the NIH (R01GM116116 and R21CA204706) for funding.

\section{References}

1. Mao, S. et al. In Situ Scatheless Cell Detachment Reveals Correlation between Adhesion Strength and Viability at Single-Cell Resolution. Angewandte Chemie International Edition. 57 (1), 236-240 (2017). 
2. Rubakhin, S.S., Romanova, E. V, Nemes, P., Sweedler, J. V Profiling metabolites and peptides in single cells. Nature Methods. 8 (4), S20S29 (2011).

3. Linwen, Z., Akos, V. Single-Cell Mass Spectrometry Approaches to Explore Cellular Heterogeneity. Angewandte Chemie International Edition. 57 (17), 4466-4477 (2017).

4. Chen, X. et al. Single-cell analysis at the threshold. Nature Biotechnology. 34, 1111, at <http://dx.doi.org/10.1038/nbt.3721> (2016).

5. Fu, Q., Tang, J., Cui, M., Xing, J., Liu, Z., Liu, S. Application of porous metal enrichment probe sampling to single cell analysis using matrixassisted laser desorption ionization time of flight mass spectrometry (MALDI-TOF-MS). Journal of Mass Spectrometry. 51 (2016).

6. Passarelli, M.K., Ewing, A.G., Winograd, N. Single-Cell Lipidomics: Characterizing and Imaging Lipids on the Surface of Individual Aplysia californica Neurons with Cluster Secondary Ion Mass Spectrometry. Analytical Chemistry. 85 (4), 2231-2238 (2013).

7. Passarelli, M.K. et al. Single-Cell Analysis: Visualizing Pharmaceutical and Metabolite Uptake in Cells with Label-Free 3D Mass Spectrometry Imaging. Analytical Chemistry. 87 (13), 6696-6702 (2015).

8. Ostrowski, S.G., Kurczy, M.E., Roddy, T.P., Winograd, N., Ewing, A.G. Secondary lon MS Imaging To Relatively Quantify Cholesterol in the Membranes of Individual Cells from Differentially Treated Populations. Analytical Chemistry. 79 (10), 3554-3560 (2007).

9. Ibáñez, A.J. et al. Mass spectrometry-based metabolomics of single yeast cells. Proceedings of the National Academy of Sciences of the United States of America. 110 (22), 8790-8794 (2013).

10. Lanni, E.J., Rubakhin, S.S., Sweedler, J. V Mass spectrometry imaging and profiling of single cells. Journal of Proteomics. 75 (16), 5036-5051 (2012).

11. Ong, T.-H., Tillmaand, E.G., Makurath, M., Rubakhin, S.S., Sweedler, J. V Mass spectrometry-based characterization of endogenous peptides and metabolites in small volume samples. Biochimica et biophysica acta. 1854 (7), 732-740 (2015).

12. Yang, Y., Huang, Y., Wu, J., Liu, N., Deng, J., Luan, T. Single-cell analysis by ambient mass spectrometry. TrAC Trends in Analytical Chemistry. 90, 14-26 (2017).

13. Sims, C.E., Allbritton, N.L. Analysis of single mammalian cells on-chip. Lab on a Chip. 7 (4), 423-440 (2007).

14. Mizuno, H., Tsuyama, N., Harada, T., Masujima, T. Live single-cell video-mass spectrometry for cellular and subcellular molecular detection and cell classification. Journal of Mass Spectrometry. 43 (12), 1692-1700 (2008).

15. Fujii, T. et al. Direct metabolomics for plant cells by live single-cell mass spectrometry. Nature Protocols. 10, 1445, at <http:/l dx.doi.org/10.1038/nprot.2015.084> (2015).

16. Esaki, T., Masujima, T. Fluorescence Probing Live Single-cell Mass Spectrometry for Direct Analysis of Organelle Metabolism. Analytical Sciences. 31 (12), 1211-1213 (2015).

17. Tsuyama, N., Mizuno, H., Tokunaga, E., Masujima, T. Live Single-Cell Molecular Analysis by Video-Mass Spectrometry. Analytical Sciences. 24 (5), 559-561 (2008).

18. Mizuno N.; Harada, T.; Masujima, T., H.. T. Live single-cell video-mass spectrometry for cellular and subcellular molecular detection and cell classification. Journal of Mass Spectrometry. (2008).

19. Phelps, M., Hamilton, J., Verbeck, G.F. Nanomanipulation-coupled nanospray mass spectrometry as an approach for single cell analysis. Review of Scientific Instruments. 85 (12), 124101 (2014).

20. Phelps, M.S., Verbeck, G.F. A lipidomics demonstration of the importance of single cell analysis. Analytical Methods. 7 (9), 3668-3670 (2015)

21. Pan, N., Rao, W., Kothapalli, N.R., Liu, R., Burgett, A.W.G., Yang, Z. The Single-Probe: A Miniaturized Multifunctional Device for Single Cell Mass Spectrometry Analysis. Analytical Chemistry. 86 (19), 9376-9380 (2014)

22. Gong, X. et al. Single Cell Analysis with Probe ESI-Mass Spectrometry: Detection of Metabolites at Cellular and Subcellular Levels. Analytical Chemistry. 86 (8), 3809-3816 (2014).

23. Lorenzo Tejedor, M., Mizuno, H., Tsuyama, N., Harada, T., Masujima, T. In Situ Molecular Analysis of Plant Tissues by Live Single-Cell Mass Spectrometry. Analytical Chemistry. 84 (12), 5221-5228 (2012).

24. Shimizu, T. et al. Live Single-Cell Plant Hormone Analysis by Video-Mass Spectrometry. Plant and Cell Physiology. 56 (7), 1287-1296 (2015).

25. Yamamoto, K. et al. Cell-specific localization of alkaloids in Catharanthus roseus stem tissue measured with Imaging MS and Single-cell MS. Proceedings of the National Academy of Sciences. 113 (14), 3891 LP-3896 (2016).

26. Date, S., Mizuno, H., Tsuyama, N., Harada, T., Masujima, T. Direct Drug Metabolism Monitoring in a Live Single Hepatic Cell by Video Mass Spectrometry. Analytical Sciences. 28 (3), 201 (2012).

27. Hiyama, E. et al. Direct Lipido-Metabolomics of Single Floating Cells for Analysis of Circulating Tumor Cells by Live Single-cell Mass Spectrometry. Analytical Sciences. 31 (12), 1215-1217 (2015).

28. Masuda, K., Abouleila, Y., Ali, A., Yanagida, T., Masujima, T. Live Single-Cell Mass Spectrometry (LSC-MS) for Plant Metabolomics. BT Plant Metabolomics: Methods and Protocols. 269-282 (2018).

29. Ferreira, C.R., Eberlin, L.S., Hallett, J.E., Cooks, R.G. Single oocyte and single embryo lipid analysis by desorption electrospray ionization mass spectrometry. Journal of Mass Spectrometry. 47 (1), 29-33 (2012).

30. Ferreira, C.R., Pirro, V., Eberlin, L.S., Hallett, J.E., Cooks, R.G. Developmental phases of individual mouse preimplantation embryos characterized by lipid signatures using desorption electrospray ionization mass spectrometry. Analytical and Bioanalytical Chemistry. $\mathbf{4 0 4}$ (10), 2915-2926 (2012).

31. Lee, J.K., Jansson, E.T., Nam, H.G., Zare, R.N. High-Resolution Live-Cell Imaging and Analysis by Laser Desorption/lonization Droplet Delivery Mass Spectrometry. Analytical Chemistry. 88 (10), 5453-5461 (2016).

32. Bergman, H.-M., Lanekoff, I. Profiling and quantifying endogenous molecules in single cells using nano-DESI MS. Analyst. 142 (19), 3639-3647 (2017).

33. Yin, L., Zhang, Z., Liu, Y., Gao, Y., Gu, J. Recent advances in single-cell analysis by mass spectrometry. Analyst. 144 (3), $824-845$ (2019).

34. González-Serrano, A.F. et al. Desorption Electrospray Ionization Mass Spectrometry Reveals Lipid Metabolism of Individual Oocytes and Embryos. PLoS ONE. 8 (9), e74981 (2013).

35. Liu, Y. et al. Study on Variation of Lipids during Different Growth Phases of Living Cyanobacteria Using Easy Ambient Sonic-Spray lonization Mass Spectrometry. Analytical Chemistry. 86 (14), 7096-7102 (2014).

36. Shrestha, B. et al. Subcellular Metabolite and Lipid Analysis of Xenopus laevis Eggs by LAESI Mass Spectrometry. PLoS ONE. 9 (12), e115173 (2014).

37. Stolee, J.A., Shrestha, B., Mengistu, G., Vertes, A. Observation of Subcellular Metabolite Gradients in Single Cells by Laser Ablation Electrospray lonization Mass Spectrometry. Angewandte Chemie International Edition. 51 (41), 10386-10389 (2012).

38. Zhang, L. et al. In Situ metabolic analysis of single plant cells by capillary microsampling and electrospray ionization mass spectrometry with ion mobility separation. Analyst. 139 (20), 5079-5085 (2014). 
39. Shrestha, B., Nemes, P., Vertes, A. Ablation and analysis of small cell populations and single cells by consecutive laser pulses. Applied Physics A. 101 (1), 121-126 (2010).

40. Stolee, J.A., Vertes, A. Toward Single-Cell Analysis by Plume Collimation in Laser Ablation Electrospray lonization Mass Spectrometry. Analytical Chemistry. 85 (7), 3592-3598 (2013).

41. Zhang, L., Vertes, A. Single-Cell Mass Spectrometry Approaches to Explore Cellular Heterogeneity. Angewandte Chemie International Edition. 57 (17), 4466-4477 (2018).

42. Onjiko, R.M., Moody, S.A., Nemes, P. Single-cell mass spectrometry reveals small molecules that affect cell fates in the 16-cell embryo. Proceedings of the National Academy of Sciences. 112 (21), 6545 LP-6550 (2015).

43. Liu, R., Pan, N., Zhu, Y., Yang, Z. T-Probe: An Integrated Microscale Device for Online In Situ Single Cell Analysis and Metabolic Profiling Using Mass Spectrometry. Analytical Chemistry. 90 (18), 11078-11085 (2018).

44. Pan, N., Rao, W., Standke, S.J., Yang, Z. Using Dicationic lon-Pairing Compounds To Enhance the Single Cell Mass Spectrometry Analysis Using the Single-Probe: A Microscale Sampling and Ionization Device. Analytical Chemistry. 88 (13), 6812-6819 (2016).

45. Sun, M., Tian, X., Yang, Z. Microscale Mass Spectrometry Analysis of Extracellular Metabolites in Live Multicellular Tumor Spheroids. Analytical Chemistry. 89 (17), 9069-9076 (2017).

46. Standke, S.J., Colby, D.H., Bensen, R.C., Burgett, A.W.G., Yang, Z. Mass Spectrometry Measurement of Single Suspended Cells Using a Combined Cell Manipulation System and a Single-Probe Device. Analytical Chemistry. 91 (3), 1738-1742 (2019).

47. Rao, W., Pan, N., Yang, Z. High Resolution Tissue Imaging Using the Single-probe Mass Spectrometry under Ambient Conditions. Journal of The American Society for Mass Spectrometry. 26 (6), 986-993 (2015).

48. Rao, W., Pan, N., Yang, Z. Applications of the Single-probe: Mass Spectrometry Imaging and Single Cell Analysis under Ambient Conditions. Journal of Visualized Experiments. (112), 53911 (2016).

49. Rao, W., Pan, N., Tian, X., Yang, Z. High-Resolution Ambient MS Imaging of Negative lons in Positive lon Mode: Using Dicationic Reagents with the Single-Probe. Journal of the American Society for Mass Spectrometry. 27 (1), 124-134 (2016).

50. Liu, R., Zhang, G., Yang, Z. Towards rapid prediction of drug-resistant cancer cell phenotypes: single cell mass spectrometry combined with machine learning. Chemical Communications. 55 (5), 616-619 (2019).

51. Sun, M., Yang, Z. Metabolomic Studies of Live Single Cancer Stem Cells Using Mass Spectrometry. Analytical Chemistry. 91 (3), $2384-2391$ (2019).

52. Tian, X., Zhang, G., Shao, Y., Yang, Z. Towards enhanced metabolomic data analysis of mass spectrometry image: Multivariate Curve Resolution and Machine Learning. Analytica Chimica Acta. 1037, 211-219 (2018).

53. Hu, P., Zhang, W., Xin, H., Deng, G. Single Cell Isolation and Analysis. Frontiers in Cell and Developmental Biology. 4, 116 (2016).

54. Wu, C., Wu, P., Zhao, H., Liu, W., Li, W. Clinical Applications of and Challenges in Single-Cell Analysis of Circulating Tumor Cells. DNA and Cell Biology. 37 (2), 78-89 (2017).

55. Schober, Y., Guenther, S., Spengler, B., Römpp, A. Single Cell Matrix-Assisted Laser Desorption/lonization Mass Spectrometry Imaging. Analytical Chemistry. 84 (15), 6293-6297 (2012).

56. Pulfer, M., Murphy, R.C. Electrospray mass spectrometry of phospholipids. Mass Spectrometry Reviews. 22 (5), $332-364$ (2003). 